\section{Alle slags fantasifulle dumheter?}

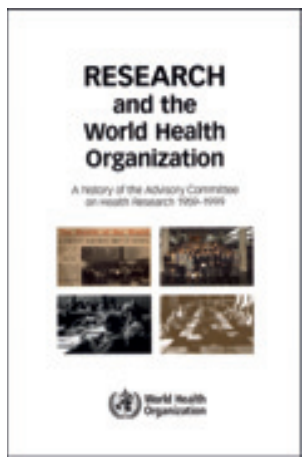

Verdens helseorganisasjon

Research and the World Health Organization

A history of the advisory committee on health research 1959-1999. $147 \mathrm{~s}$, tab, ill.

Genève: WHO, 2010. Pris CHF 30

ISBN 978-92-4-156411-3

«Det er sørgelig at medlemslandene bruker WHOs ressurser til å gjøre alle slags fantasifulle dumheter som å kjøpe litt DDT eller biler, eller sende en fyr hit eller dit, i stedet for å bruke dem til å sette seg ned for å forstå sine egne vanskeligheter.» Slik lød det i 1986 da generalsekretæren, danske Halfdan Mahler (f. 1923), beklaget seg over manglende fremdrift i helsetjenesteforskningen.

Den foreliggende utgivelsen er et bakgrunnsdokument for utviklingen av en strategi for helseforskning, vedtatt på helseforsamlingen i mai 2010. Det er en historisk oppsummering av arbeidet til WHOs rådgivende komité for helseforskning fra starten i 1959 og frem til 1999. Selv om det ikke er uttrykt må man derfor anta at det er helseforsamlingen som er målgruppen, dvs. representanter for verdens helseministre. Historien til rådgivningskomiteen er parallell med WHOs historie: Til å begynne med la man vekt på infeksjonssykdommene, etter Alma Ata-konferansen (1978) var det hovedvekt på primærhelsetjenesten, senere ble det å bygge lokal forskningskapasitet et sentralt tema og til sist de utfordringene som ulikheter i helse innebærer.

Allerede på den andre helseforsamlingen i 1949, som ble ledet av Karl Evang (1902-81), ble prinsippene for forskning i WHO vedtatt. Disse har vært gjeldende gjennom hele førtiårsperioden som utgivelsen omfatter:

- Forskning og koordinering av forskning er essensielle funksjoner

- Førsteprioritet skal gis til forskning som er direkte relatert til WHOs programmer

- Lokalt støttet forskning skal stimulere til at ansvaret overtas lokalt

- WHO skal ikke etablere egne forskningsinstitusjoner

Organisasjonen har i stedet satset på samarbeidende sentre og laboratorier i mange land, ekspertpaneler og tekniske komitéer. I 1965 ble det internasjonale kreftforskningsinstituttet (IARC) etablert som et selvstendig organ innen WHO.

Rett skal være rett - ikke alt var fantasifulle dumheter. WHOs Special Programme for Research and Training in Tropical Diseases (TDR) og de andre spesialprogrammene har utvilsomt vært instrumentelle i å fremme helseforskningen i mange land i Afrika. Dette har vært et stort og viktig bidrag, men blir bare summarisk nevnt blant en jevn strøm av usortert stort og smått. Dette er min hovedinnvending mot denne utgivelsen som allment opplysende: Den er for kort og overfladisk til å yte WHOs forskningspolitiske innsats rettferdighet og er skrevet med for lite kritisk distanse til å kunne gi balanserte og interessante fremstillinger av de konfliktlinjer og interesseavveiinger som er en del av historien. Og som vanlig i WHO-utgivelser glimrer de siste med sitt fravær.

«Tiden er ikke på vår side. Befolkningen øker. Fattigdommen øker. Urbaniseringen frembringer nye miljøproblemer. I noen land ser det ut å være et begynnende sammenbrudd i den institusjonelle orden. Under slike omstendigheter blir det stadig vanskeligere å overføre kunnskap som, hvis den ble anvendt, kunne hjelpe til med å nå WHOs mål.» Dette sa lord Zuckerman (1904-93) på en rundebordskonferanse i 1975. Det kunne dessverre like gjerne vært sagt i dag.

\section{Lite nyttig oppslagsbok}

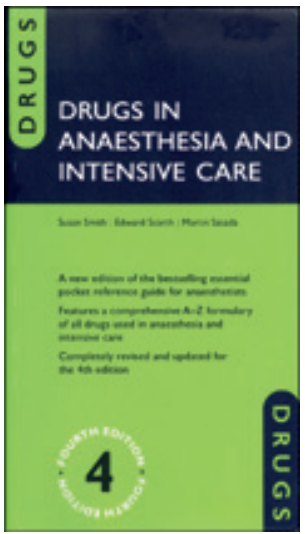
Susan Smith, Edward Scarth, Martin Sasada
Drugs in anaesthesia and intensive care 4. utg. 390 s. Oxford: Oxford University Press, 2011. Pris GBP 28 ISBN 978-0-19-959938-7

Denne utgivelsen omfatter en alfabetisk opplistet beskrivelse av medikamenter brukt for anestesi og intensivmedisin. For hvert enkelt medikament er det angitt indikasjoner, virkningsmekanisme, administrasjonsform, bivirkninger og farmakologiske egenskaper det vil si en presentasjon ikke ulik den norske Felleskatalogen, men beregnet for frakkelommen.

Ved forsøk på å slå opp på noen aktuelle legemidler finner jeg enkelte mangler i beskrivelsen. Noen eksempler: For acetazolamid mangler beskrivelse av bruk ved metabolsk alkalose. Impipenem og meropenem finnes ikke som egne oppslag eller i innholdsfortegnelsen, men er beskrevet under fellesbetegnelsen karbapenemer, slik at mange ikke vil finne medikamentene ved et raskt oppslag. Morfin er angitt i dosen $\mathrm{mg} / \mathrm{kg}$. Det er ikke i tråd med vanlig dosering for voksne. For mange antibiotika, bl.a. aminoglykosider, er det ikke gitt en anbefalt dose. Det står heller ikke at aminoglykosider normalt bør doseres en gang daglig. Mange viktige antibiotika, f.eks. vankomycin, linezolid eller piparacillin-tazobactam finnes ikke. Heller ikke soppbehandling er inkludert. Det er også vanskelig å forstå at det ikke er beskrevet dosering av medikamenter under kontinuerlig hemodiafiltrasjon, kanskje den situasjonen hvor intensivmedisinere hyppigst tyr til oppslagsverk for dosering av legemidler.

Denne boken har liten nytteverdi. Mange relevante medikamenter er ikke omtalt, og for mange av legemidlene er informasjonen mangelfull. For de fleste medikamentene gir Felleskatalogen like god eller bedre informasjon. For de legemidlene som ikke er registrert i Norge, finnes bedre informasjon i andre oppslagsverk, f.eks. det svenske legemiddelregisterets nettsted www.fass.se.

\section{Pål Klepstad}

Intensivavdelingen

St. Olavs hospital 